\title{
Patent law changes opposed in the Senate
}

ATtempts to liberalise US patent laws by granting universities - and small businesses - exclusive rights to patents from federally-funded research have run into stiff opposition in the Senate on the grounds that they are selling out the American tax-payer.

Many leading research universities have campaigned actively in support of a bill, introduced by Senator Birch Bayh and Senator Robert Dole, which would grant such exclusive rights to any university or small business able to show that it is prepared to spend additional funds on encouraging the exploitation of the patent.

However, when the bill, which has been unanimously approved by the Senate Judiciary Committee, was introduced on the floor of the Senate last month, it ran into unexpectedly vehement opposition from Senator Russell Long, powerful chairman of the Finance Committtee and long an opponent of apparent monopoly practices.

Senator Long threatened to filibuster the bill, hinting that this might place in jeopardy the progress of windfall profits legislation on the oil industry. The bill was quickly withdrawn from the debate by Senate leaders, worried that it might otherwise be lost, but is expected to be brought up again shortly.

Meanwhile Senator Long sent a letter to his Senate colleagues last week outlining his opposition to measures which he said represented a "radical and far-reaching giveaway" by the federal government, and would if passed "wipe out every law on the books which reserves for the public the paid results of [federally-financed] research".

Patent law revision has become one of the cornerstones of current attempts both within Congress and by the Carter administration to create an environment considered more conducive to technological innovation by private industry.

The Bayh Bill attracted over 50 cosponsors when it reached the floor of the Senate. In speaking to the bill, Senator Bayh repeated a common complaint that although the government lacked the resources to develop and market products arising from federal research, it was unwilling to relinquish patent rights in a way that would encourage others to do so.

Similar arguments were heard from others in the debate. Senator Strom Thurmond pointed out that universities had successfully licensed $33 \%$ of the patents that they held, whereas $95 \%$ of the patents owned by the government had never been exploited. And Senator Edward Kennedy argued that, by helping raise the general level of economic competition, the legislation "would help America retain its competitive edge in technology and innovation".

To refute charges that the government is selling out investments in research made by the US tax-payer, the bill contains a formula by which funds will be returned to the government from those inventions that eventually enjoy substantial success.

But this has not dampened Senator Long's opposition. In his letter to Senate colleagues he agrees that economic growth and increased productivity "require the most rapid dissemination of scientific and technological knowledge" - but argues that allowing firms to file private patents would do the opposite by "bottling up" technical information.

In support he quotes Nobel Prize winner Wassily Leontief, Admiral Hyman Rickover, and Michael Pertschuk, Chairman of the Federal Trade Commission, who told a Senate committee in 1977 that there was no basis for claims that giving away title to private contractors promotes commercialisation of government-financed invention, and that the available evidence "shows the opposite".

\section{Third World research institute loses Congressional approval}

THE Carter administration seems to have failed in its attempts to establish a new body to promote scientific and technological research efforts relevant to the needs of developing countries, known as the Institute for Scientific and Technological Cooperation (ISTC).

Delegates from the Senate and the House of Representatives, meeting last week to resolve differences of opinion over foreign aid spending in 1980 , agreed to allocate $\$ 12$ million to the Agency for International Development (AID) to support programmes of scientific and technical cooperation - but rejected the proposal to establish a new institute to carry out such programmes.

Thus although the institute legally came into existence last October, following agreement between the two legislative bodies on authorising legislation, all of its activities will now be incorporated within AID, with responsibilities that were to have been delegated by Congress to the director of the ISTC now being assumed by the administrator of AID.

The rejection of the ISTC by Congress, which seems inevitable even though the conference report could theoretically be objected to by either House, is a major blow to the administration, particularly since the institute figured prominently in the US presentation to the United Nations Conference on Science and Technology for development in Vienna last August.

From the beginning, administration officials have argued that the new institute, plans for which were first announced by President Carter in a speech in Caracas in 1978, would not be acceptable to Congress if it was run by a totally independent board - an alternative proposal actively canvassed by some scientists - but that a new body operating under the broad unbrella of AID should be acceptable.

Many in Congress have not been convinced by the arguments for a new institute. In particular, Senator Peter Deconcini last summer persuaded the Senate to reject authorisation plans for the institute on the grounds that it would create unnecessary additional bureaucracy.

This decision was reversed in meetings with the House of Representatives on the authorising legislation. But Senator Deconcini used the same argument last October to persuade the Senate to cut off funds for the institute, and this time his arguments prevailed in conference, although House delegates managed to argue the extra money for the AID budget.

Administration officials are debating whether, now ISTC has been authorised but not funded, they should push ahead for the $\$ 95$ million requested for the institute in the 1981 request. But such a move could jeopardise the $\$ 15$ million requested for the new Science and Technology Fund being set up by the United Nations Development Programme, which has already been cut back to $\$ 10$ million by a House subcommittee.

Those who have been following the changing fortunes of the ISTC in Washington last week expressed disappointment, but little surprise, at the outcome, since the debate over the institute has become bogged down in a political climate increasingly unsympathetic to providing assistance to Third World countries.

However some now feel that the time may be ripe for other initatives. The National Science Foundation, for example, has recently announced a new programme to encourage US universities to establish links with Third World research groups. Others are suggesting that private foundations might be persuaded to support a scaled-down version of the original ISTC proposal. 